\title{
A Holocene black carbon ice-core record of biomass burning in the Amazon Basin from Illimani, Bolivia
}

\author{
Dimitri Osmont $^{1,2,3}$, Michael Sigl ${ }^{1,2}$, Anja Eichler ${ }^{1,2}$, Theo M. Jenk ${ }^{1,2}$, and Margit Schwikowski ${ }^{1,2,3}$ \\ ${ }^{1}$ Laboratory of Environmental Chemistry, Paul Scherrer Institute, 5232 Villigen, Switzerland \\ ${ }^{2}$ Oeschger Centre for Climate Change Research, University of Bern, 3012 Bern, Switzerland \\ ${ }^{3}$ Department of Chemistry and Biochemistry, University of Bern, 3012 Bern, Switzerland
}

Correspondence: Margit Schwikowski (margit.schwikowski@psi.ch)

Received: 10 October 2018 - Discussion started: 16 October 2018

Revised: 26 February 2019 - Accepted: 14 March 2019 - Published: 28 March 2019

\begin{abstract}
The Amazon Basin is one of the major contributors to global biomass burning emissions. However, regional paleofire trends remain particularly unknown. Due to their proximity to the Amazon Basin, Andean ice cores are suitable to reconstruct paleofire trends in South America and improve our understanding of the complex linkages between fires, climate and humans. Here we present the first refractory black carbon ( $\mathrm{rBC}$ ) ice-core record from the Andes as a proxy for biomass burning emissions in the Amazon Basin, derived from an ice core drilled at $6300 \mathrm{~m}$ a.s.l. from the Illimani glacier in the Bolivian Andes and spanning the entire Holocene back to the last deglaciation 13000 years ago. The Illimani rBC record displays a strong seasonality with low values during the wet season and high values during the dry season due to the combination of enhanced biomass burning emissions in the Amazon Basin and less precipitation at the Illimani site. Significant positive (negative) correlations were found with reanalyzed temperature (precipitation) data for regions in eastern Bolivia and western Brazil characterized by substantial fire activity. rBC long-term trends indirectly reflect regional climatic variations through changing biomass burning emissions as they show higher (lower) concentrations during warm-dry (cold-wet) periods, in line with climate variations such as the Younger Dryas, the $8.2 \mathrm{ka}$ event, the Holocene Climatic Optimum, the Medieval Warm Period and the Little Ice Age. The highest $\mathrm{rBC}$ concentrations of the entire record occurred during the Holocene Climatic Optimum between 7000 and $3000 \mathrm{BCE}$, suggesting that this exceptionally warm and dry period caused high levels of biomass burning activity, unprecedented in the context of the past 13000 years. Recent rBC levels, rising since $1730 \mathrm{CE}$ in
\end{abstract}

the context of increasing temperatures and deforestation, are similar to those of the Medieval Warm Period. No decrease in fire activity was observed in the 20th century, in contradiction to global biomass burning reconstructions based on charcoal data.

\section{Introduction}

Fires play a major role in the global carbon cycle by emitting aerosols and greenhouse gases. Current global $\mathrm{CO}_{2}$ emissions due to biomass burning represent $\sim 50 \%$ of those originating from fossil fuel combustion (Bowman et al., 2009). The mean annual burned area worldwide amounts to 348 Mha for the time period 1997-2011 (Giglio et al., 2013). South America is, after Africa, the second most affected region by biomass burning, accounting for $16 \%$ to $27 \%$ of the global annual burned area between 1997 and 2004 (Kloster et al., 2010; Schultz et al., 2008) and leading to carbon emissions ranging from $\sim 300$ to $900 \mathrm{TgC} \mathrm{yr}^{-1}$ (Kloster et al., 2010; Schultz et al., 2008). Biomass burning mainly occurs in Southern Hemisphere South America, representing 13.6\% of the global annual carbon emissions from biomass burning (van der Werf et al., 2010). Brazil and Bolivia are the two countries most affected, accounting for $60 \%$ and $10 \%$ of active fire observations, respectively (Chen et al., 2013). Savannas (cerrados) and seasonally dry tropical forests (SDTFs) located at the southern edge of the Amazon Basin are prone to extensive fires during the dry season between June and October, when many fires are ignited for land clearance purposes for agriculture and grazing (Mouillot and Field, 2005; Power et al., 2016). Savanna burned area over South Amer- 
ica remained fairly stable over the 20th century (Mouillot and Field, 2005; Schultz et al., 2008). However, this trend masks regional discrepancies: while burning decreased along the Brazilian coast, it has strongly increased in the western part due to deforestation (Mouillot and Field, 2005). In contrast, tropical rain forests centered further north in the Amazon Basin rarely burn naturally due to persistent moist conditions and limited dry lightning (Bowman et al., 2011; Cochrane, 2003), but since the 1960s they have experienced intensive deforestation fires at their southern edge, known as the "arc of deforestation" (Cochrane et al., 1999). Southern Hemisphere South America accounted for $37 \%$ of all deforestation fires worldwide over the time period 2001-2009 (van der Werf et al., 2010). However, the contribution from deforestation fires to the total number of fires observed in South America seems to have decreased since 2005, particularly in Brazil due to stricter environmental policies, while fire activity significantly increased in Bolivia (Chen et al., 2013). A similar observation was made by van Marle et al. (2017a), who reported a strong increase in deforestation fires in the 1990s followed by a general decline since the 2000s.

For the time period before the start of satellite measurements (1980s), the lack of accurate data from the Amazon Basin hinders a detailed reconstruction of fire history. Historical reconstructions based on fire statistics, land-use practices, and vegetation type and history have shown a dramatic increase in fires in the forested parts of South America over the last decades, mainly because of deforestation, as fires were almost absent from the Amazon Basin before the 1960s (Mouillot and Field, 2005). Charcoal records from lake sediment cores were the only way to infer paleofire trends in this region before the 20th century. They revealed that biomass burning trends in tropical South America were less pronounced than in other regions of the Americas, underlining the absence of a clear driver for biomass burning, possibly due to the large diversity of climate, vegetation and topography in this region (Power et al., 2012). Nevertheless, the last 2000 years showed an overall slight decrease in fire activity until around $1800 \mathrm{CE}$, followed by a strong increase in the 20th century (Power et al., 2012). This is in contradiction to the global trend, suggesting a decoupling since $1870 \mathrm{CE}$ between the decreasing biomass burning trend and its main drivers, namely increasing temperature and population density, due to fire management and the global expansion of intensive agriculture and grazing leading to landscape fragmentation (Marlon et al., 2008). Composite charcoal records for tropical South America display a great variability through the entire Holocene, with higher-than-present biomass burning levels in the mid-Holocene between 6500 and $4500 \mathrm{BP}$ (Marlon et al., 2013). However, charcoal records only reflect local to regional conditions and therefore have to be compiled to extract a regional signal, while ice cores have the potential to integrate information over continental scales (Kehrwald et al., 2013). Ice-core records from Antarctica have already been connected to paleofire trends in the South- ern Hemisphere. They revealed elevated biomass burning activity around 8000 to $6000 \mathrm{BP}$ in southern America (Arienzo et al., 2017) and confirmed an overall agreement with the aforementioned global trend (Wang et al., 2010). But given the remoteness of the Antarctic continent, limitations may arise from transport patterns, thus advocating for the use of ice-core records located closer to the source regions.

As the major moisture source in the tropical Andes is the Amazon Basin and ultimately the Atlantic Ocean (Garreaud et al., 2003; Vuille et al., 2003), ice cores from tropical Andean glaciers could serve as potential archives of past biomass burning trends in the Amazon Basin and thus form the missing link between South American lake sediment charcoal records and Antarctic ice-core records, which could be helpful to better constrain fire models and historical fire databases (van Marle et al., 2017b). However, the preservation of a biomass burning signal in tropical Andean ice cores has never been extensively investigated. The charcoal record from the Sajama ice core (Bolivia) did not suggest marked changes in biomass burning activity over the last 25000 years, except in the most recent sample due to increasing anthropogenic burning and ore smelting (Reese et al., 2013). Nearby sedimentary charcoal records do show a biomass burning variability in the Bolivian Amazonian lowlands through the Holocene (Brugger et al., 2016; Power et al., 2016), with enhanced burning during warmer-drier periods such as the early to mid-Holocene (approximately from 8000 to $5500 \mathrm{BP}$; Baker et al., 2001), and limited burning during colder-wetter periods such as the last deglaciation or the Little Ice Age.

Ice-core studies suggest that a variety of biomass burning proxies could be used to reconstruct paleofires (Osmont et al., 2018; Zennaro et al., 2014). Ammonium $\left(\mathrm{NH}_{4}^{+}\right)$has been widely analyzed in polar ice cores from Greenland (Fischer et al., 2015; Legrand et al., 2016) and Antarctica (Arienzo et al., 2017). Simple organic acids (formate, oxalate) were also considered, but they can experience postdepositional effects (Legrand et al., 2016). However, these compounds are not specific proxies as they also reflect continuous biogenic emissions from vegetation and soils in their background variations, while only peak values can be associated with biomass burning events (Fischer et al., 2015). Black carbon (BC), produced by the incomplete combustion of biomass and fossil fuels (Bond et al., 2013), has the advantage of being a specific proxy for biomass burning in preindustrial times, when no significant anthropogenic sources existed. Aerosol source apportionment studies in Amazonia have shown that recent $\mathrm{BC}$ emissions in this region originate only from biomass burning (Artaxo et al., 1998). However, in the Andean region, it has been shown that recent BC anthropogenic emissions from urban areas, particularly from traffic, could reach high-elevation sites (Wiedensholer et al., 2018) and potentially affect local glacier melting (Molina et al., 2015; Schmitt et al., 2015). An increasing anthropogenic $\mathrm{BC}$ contribution from fossil fuel combustion has also been 
observed in ice cores from Greenland (Keegan et al., 2014; McConnell et al., 2007; Sigl et al., 2013) and the Alps (Jenk et al., 2006; Lavanchy et al., 1999; Sigl et al., 2018) since the second half of the 19th century and from eastern Europe (Lim et al., 2017) and Asia (Kaspari et al., 2011; Wang et al., 2015 ) in the last decades.

Here, we present the first Andean BC ice-core record, derived from the analysis of the Illimani 1999 (IL-99) ice core. When referring to our measurements using the laserinduced incandescence method, the term refractory black carbon (rBC) will be employed, following the recommendations of Petzold et al. (2013). After discussing the seasonality of the $\mathrm{rBC}$ signal and the connections with regional climate parameters and biomass burning, we will present rBC longterm trends of the last millennium and through the Holocene, link them with climate variability, and compare them to existing ice-core and lake sediment records.

\section{Methods}

\subsection{Ice-core and site characteristics}

In June 1999, two ice cores were drilled at $6300 \mathrm{~m}$ a.s.l. on Nevado Illimani, Bolivia, on a glacier saddle between the summits of Pico Central and Pico Sur $\left(16^{\circ} 39^{\prime} \mathrm{S}, 67^{\circ} 47^{\prime} \mathrm{W}\right.$; Fig. 1) by a joint French-Swiss team from the Institut de Recherche pour le Développement (IRD, France) and the Paul Scherrer Institute (PSI, Switzerland) using the Fast Electromechanical Lightweight Ice Coring System (FELICS; Ginot et al., 2002a). Bedrock was reached at $136.7 \mathrm{~m}$ of depth (French core) and $138.7 \mathrm{~m}$ of depth (Swiss core, this study). Low borehole temperatures $\left(<-7^{\circ} \mathrm{C}\right)$ and very few ice lenses indicative of meltwater percolation ensured a good preservation of the chemical signal recorded in the ice core (Kellerhals et al., 2010a). Further details can be found in Knüsel et al. (2003) and Knüsel et al. (2005). Bonnaveira (2004) investigated post-depositional effects such as sublimation and wind scouring and showed that their influence on the preservation of ionic species remained limited compared to actual seasonal variations in concentration.

The climate of the Bolivian Altiplano is characterized by a wet season during the austral summer (November-March) and a dry season during the austral winter (April-October). Moisture mainly originates from the Amazon Basin and ultimately from the Atlantic Ocean (Garreaud et al., 2003; Vuille et al., 2003). Moreover, an interannual variability in precipitation is induced by El Niño-Southern Oscillation (ENSO) processes. El Niño years tend to be drier on average as they inhibit moisture influx from the east, whereas La Niña years are usually wetter (Garreaud and Aceituno, 2001; Garreaud et al., 2003). The Illimani site, located on the eastern margin of the Altiplano, can also receive moisture influx during the dry season, leading to a less pronounced seasonality with summer months (December-January-February) representing only $50 \%-60 \%$ of the annual mean precipitation (Garreaud

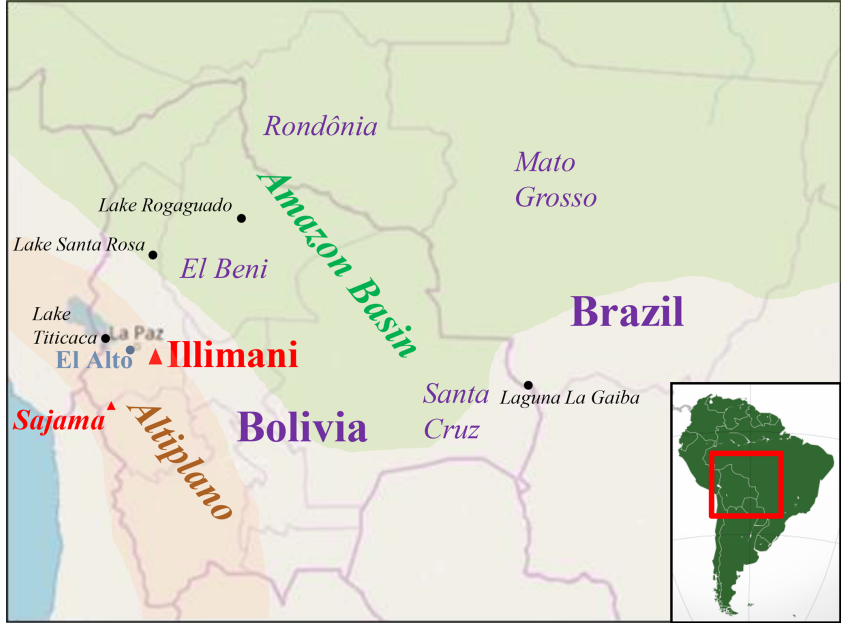

Figure 1. Map showing the location of Nevado Illimani in Bolivia and the other sites and regions of interest in Bolivia and Brazil mentioned in the study (adapted from http://openstreetmap.org, last access: 12 June 2018).

et al., 2003). This trend is also reflected in the Illimani icecore record compared to other Andean ice-core sites showing a more pronounced seasonality (Ginot et al., 2002b). Similarly, the precipitation modulation by ENSO remains weaker at the Illimani site compared to the western Andes (Garreaud et al., 2003; Vuille et al., 2000).

The IL-99 ice core has already been widely studied. Knüsel et al. (2005) investigated the potential impact of ENSO on the ionic records, revealing elevated dust values during warm phases of ENSO. Kellerhals et al. (2010b) used thallium as a possible volcanic eruption tracer. Kellerhals et al. (2010a) produced a regional temperature reconstruction for the last 1600 years based on the $\mathrm{NH}_{4}^{+}$record. Eichler et al. (2015) focused on the historical reconstruction of regional silver production and recent leaded gasoline pollution based on the lead record. Finally, Eichler et al. (2017) made use of the copper record to reconstruct copper metallurgy, showing that the earliest extensive copper metallurgy started in the Andes 2700 years ago.

\subsection{Ice-core dating}

Dating of the core was performed by using a multiparameter approach combining annual layer counting of the electrical conductivity signal, reference horizons such as the $1963 \mathrm{CE}$ nuclear fallout peak and volcanic eruptions $(1258,1815$, $1883,1963,1982$ and $1991 \mathrm{CE}$ ), the ${ }^{210} \mathrm{~Pb}$ decay (Knüsel et al., 2003), and ${ }^{14} \mathrm{C}$ dating (Kellerhals et al., 2010a). A continuous age-depth relationship was established by fitting a two-parameter glacier flow model through the reference horizons, except between the last five ${ }^{14} \mathrm{C}$ ages for which linear interpolation was used due to the very strong layer thinning (Kellerhals et al., 2010a), resulting in a bot- 
tom age of 13000 years BP and an overall accumulation rate of $0.58 \mathrm{~m} \mathrm{yr}^{-1}$ weq (water equivalent). Dating uncertainty is estimated to be \pm 2 years in the vicinity of volcanic horizons and \pm 5 years otherwise back to $1800 \mathrm{CE}, \pm 20$ years for the time period $1250-1800 \mathrm{CE}$ and \pm 110 years at the youngest ${ }^{14} \mathrm{C}$ age (1060-1280 BP; Kellerhals et al., 2010a).

\subsection{Sampling and $\mathrm{rBC}$ analysis}

The IL-99 ice core was cut for $\mathrm{rBC}$ analysis into $1.9 \times 1.9 \mathrm{~cm}$ sections from the inner part of the core in a $-20^{\circ} \mathrm{C}$ cold room at PSI following clean protocols (Eichler et al., 2000). Sampling resolution was $10 \mathrm{~cm}$ for the first 316 samples down to $33.15 \mathrm{~m}$ of depth (spanning 1966-1999 CE) and 3-4 cm for the remaining 2754 samples below $33.15 \mathrm{~m}$ down to the bottom. A total of 3070 samples was obtained. 243 replicates from parallel ice-core sticks were cut from 12 different ice-core sections to check the reproducibility of our analyses. Furthermore, the section between 127.4 and $133 \mathrm{~m}$ of depth (spanning roughly 0-2000 BC) was resampled at 3$7 \mathrm{~cm}$ resolution (121 samples) specifically due to poor icecore quality (chips). Samples for the $\mathrm{rBC}$ analyses were collected in pre-cleaned $50 \mathrm{~mL}$ polypropylene tubes and stored at $-20^{\circ} \mathrm{C}$.

The entire IL-99 ice core was analyzed for rBC at PSI between April and June 2017, following the method described by Wendl et al. (2014). After melting the ice-core samples at room temperature and $25 \mathrm{~min}$ sonication in an ultrasonic bath, rBC was quantified using a single-particle soot photometer (SP2, Droplet Measurement Technologies, USA; Schwarz et al., 2006; Stephens et al., 2003) coupled to an APEX-Q jet nebulizer (Elemental Scientific Inc., USA). Further analytical details regarding calibration, reproducibility and autosampling method can be found in Osmont et al. (2018). Replicate samples for the IL-99 ice core showed good reproducibility ( $r=0.65, p<0.001, n=243$ ), in particular regarding $\mathrm{rBC}$ peak values and trends, while the resampled part in the period 0-2000 BCE (121 samples) showed notable agreement with the original dataset, thus confirming the reliability of our $\mathrm{rBC}$ analysis.

\section{Results and discussion}

\section{1 rBC seasonal variability in the Illimani ice core}

The Illimani $\mathrm{rBC}$ record displays a strong seasonal variability, with high concentrations corresponding to the maximum of the dry season (June-October) and low concentrations during the wet season (November-March). In the IL-99 ice core, peak values typically range between 2 and $10 \mathrm{ng} \mathrm{g}^{-1}$, with a high year-to-year variability and a maximum of $13.3 \mathrm{ng} \mathrm{g}^{-1}$ in 1996, while the wet season background remains fairly constant, below $0.5 \mathrm{ng} \mathrm{g}^{-1}$ (Fig. 2a). The observed $\mathrm{rBC}$ seasonality is similar to previous observations made on records of trace elements (Correia et al., 2003) and major ions (Knüsel et al., 2005; Fig. 2b-c), reflecting the seasonality in precipitation (Fig. 2d). During the wet season, abundant precipitation occurs, which dilutes the chemical signal in the snow, whereas during the dry season, the small amount of precipitation leads to highly concentrated wet deposition and also enables dry deposition of dust particles (Bonnaveira, 2004; Correia et al., 2003; De Angelis et al., 2003). Bonnaveira (2004) noted that an Amazonian biomass burning contribution was expressed in the concentrations of organic species (e.g., oxalate) at the end of the dry season (August-October) in aerosols collected at Plataforma Zongo, $40 \mathrm{~km}$ north of the Illimani site (Bolivia). The seasonal signal in the Illimani ice core is therefore mainly the result of transport to and deposition at the Illimani site combined with the fact that dust mobilization from the Altiplano (Kellerhals et al., 2010a; Knüsel et al., 2005) and biomass burning emissions in the Amazon Basin also peak during the dry season (Mouillot and Field, 2005; Power et al., 2016).

\subsection{Connection with climate parameters in South America during the 20th century}

During the last century, rBC concentrations did not show an evident long-term trend, but decadal peaks were visible in the 1900s, 1940s and 1960s (Fig. 3a). These maxima do not agree with model-based BC emissions (Fig. 3c). We extracted the time series of $\mathrm{BC}$ emissions from biomass burning for the $5 \times 5^{\circ}$ grid cell containing the Illimani site used in the Coupled Model Intercomparison Project Phase 6 (CMIP6) simulations (van Marle et al., 2017b) and compared it to the IL-99 rBC record for the time period 1900-2000. Even if all the $\mathrm{BC}$ emissions recorded at Illimani are not expected to come solely from this grid cell, it is striking to note that estimated BC emissions remained perfectly constant until the start of satellite measurements in the 1980s, when the data coverage greatly improved. Estimated BC emissions subsequently exhibited much more variability and increased by more than 1 order of magnitude until the late 1990s. A direct relationship between the $\mathrm{rBC}$ record and biomass burning trends in the Amazon Basin before 1999 cannot be assessed due to the lack of accurate biomass burning statistics from Bolivia and Brazil, where the number of active fires is retrieved from satellite data only starting in 1998. In addition, data about the burned area remain scarce and are associated with larger uncertainties despite their greater significance in terms of environmental impacts and aerosol emissions (Montellano, 2012).

For investigating major causes of $\mathrm{rBC}$ changes during the 20th century, we studied spatial and temporal correlations between the IL-99 rBC record and two important drivers of biomass burning activity, namely temperature and precipitation. Significant correlations $(p<0.05)$ between the IL$99 \mathrm{rBC}$ record and reanalyzed temperature and precipitation from the NCEP-NCAR R1 dataset were found for areas in the Amazon Basin located east of the Illimani site, which are 

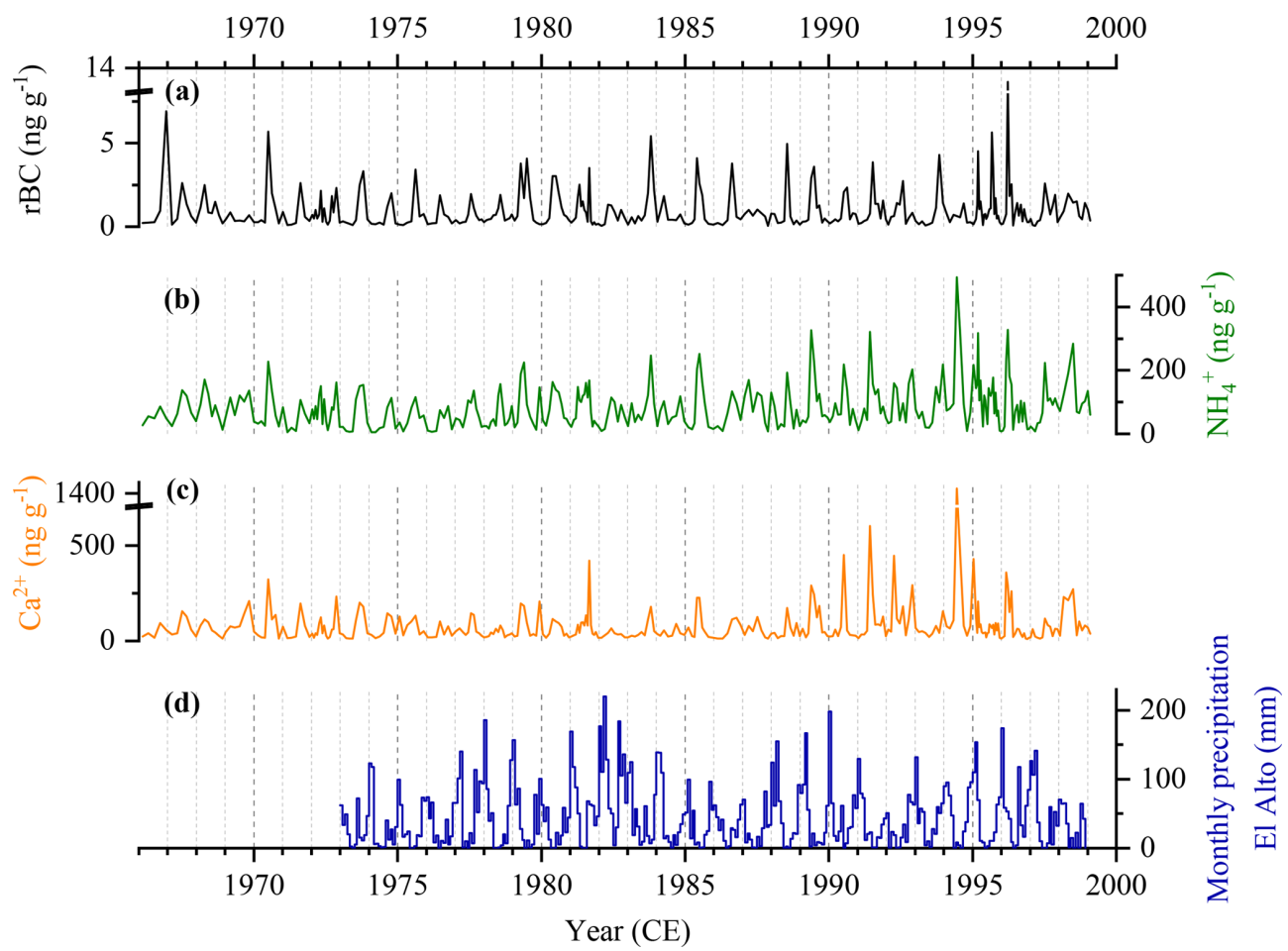

Figure 2. Concentrations of (a) rBC, (b) ammonium and (c) calcium in the upper $33.15 \mathrm{~m}$ of the IL-99 ice core (raw data). (d) Monthly precipitation data from El Alto weather station, located $40 \mathrm{~km}$ west of Illimani near the city of La Paz. Data are available on the website of the US National Climatic Data Center (NCDC) at the following address: https://www7.ncdc.noaa.gov/CDO/cdoselect.cmd?datasetabbv=GSOD (last access: 25 July 2018).

assumed to be the main source regions of the rBC deposited at Illimani (Fig. 4). 5-year moving means were used owing to the ice-core dating uncertainty, which prevents detection of an annual connection with temperature and precipitation data. Positive correlations with temperature are highest along the arc of deforestation in Brazil and in regions of eastern Bolivia (states of El Beni and Santa Cruz) and western Brazil (state of Rondônia and Mato Grosso) where extensive fires occur during the dry season. Similarly, negative correlations with precipitation are highest along the Bolivian-Brazilian border for the states of Santa Cruz and Mato Grosso. Comparisons between temperature-precipitation time series for the Amazon Basin (defined here as the region between $4^{\circ} \mathrm{N}-$ $16^{\circ} \mathrm{S}$ and $76-51^{\circ} \mathrm{W}$ ) and the IL-99 $\mathrm{rBC}$ record confirm that higher $\mathrm{rBC}$ concentrations are observed during warmer and drier periods, such as the 1900s, the 1940s and the 1960s (Fig. 3d and e). Different temperature-precipitation datasets were used to highlight their strong variability, but the main conclusion remains unchanged. Depending on the dataset used, variations in temperature and precipitation account for $18 \%-64 \%$ and $1 \%-18 \%$ of the $\mathrm{rBC}$ variance, respectively. However, the correlation between the IL-99 rBC record and precipitation datasets is never significant at the 0.05 level, suggesting a predominant influence of temperature on regional fire activity.
Potential connections between the IL-99 rBC record and the ENSO phenomenon were also investigated. In general, and similarly to the Altiplano, El Niño phases of ENSO induce drier and warmer conditions over the Amazon Basin, while La Niña phases are wetter and cooler (Aceituno, 1988; Foley et al., 2002; Garreaud et al., 2009). The trend is more pronounced during the wet season (Garreaud et al., 2009). However, this relationship weakens towards the western part of the Amazon Basin (Garreaud et al., 2009; Ronchail et al., 2002) and becomes more complex on the Bolivian slopes between the Amazon Basin and the Altiplano, as opposite effects can be observed depending on the altitude (Ronchail and Gallaire, 2006). To determine whether ENSO can modulate $\mathrm{rBC}$ concentrations in the Illimani ice core, we compared the 20th century IL-99 $\mathrm{rBC}$ record to the multivariate ENSO index (MEI; Fig. 3b) spanning 1950-2018 (Wolter and Timlin, 1993, 1998) and the extended MEI reaching back to 1871 (Wolter and Timlin, 2011). The low correlation coefficient between the $\mathrm{rBC}$ record and the MEI indicates no evident impact of ENSO. Interestingly, the highest two rBC annual values occurred during some of the most extreme El Niño events (1905-1906 and 1941), but rBC values can also remain low during strong El Niño phases, for instance in 19291930. Conversely, rBC annual values are not necessarily low during intense La Niña phases, as seen in 1910, 1917 and 


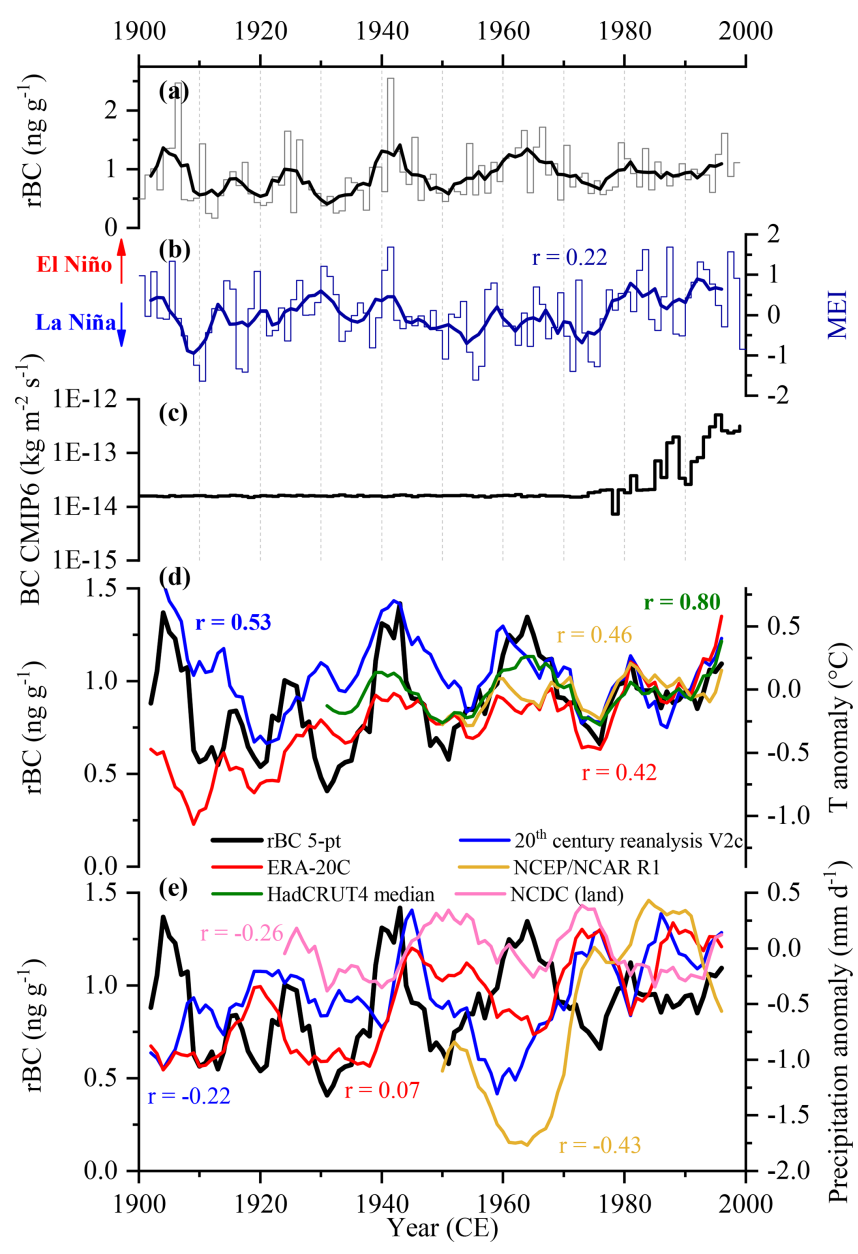

Figure 3. Comparison of the IL-99 rBC record with South American climate parameters for the time period 1900-2000 CE. (a) rBC record from the IL-99 ice core (thin lines: annual mean, thick lines: 5-year moving mean). (b) Multivariate ENSO index (MEI; thin lines: annual mean, thick lines: 5-year moving mean; Wolter and Timlin, 1993, 1998, 2011), with a higher (lower) value standing for a stronger El Niño (La Niña) event. The extended MEI is used before 1950. (c) Annual BC emissions derived from the CMIP6 simulations for the $5 \times 5^{\circ}$ grid cell containing the Illimani site (van Marle et al., 2017b). Comparison between the IL-99 rBC record and four (d) temperature and (e) precipitation datasets for the Amazon Basin $\left(4^{\circ} \mathrm{N}-16^{\circ} \mathrm{S}\right.$ and $\left.51-76^{\circ} \mathrm{W}\right)$. Data are 5-year moving means and were extracted from the KNMI Climate Explorer. Anomalies are relative to the years 1971-2010. Pearson correlation coefficients between the IL-99 $\mathrm{rBC}$ record and the associated climate datasets were calculated based on 5-year moving means, and coefficients in bold are statistically significant at the 0.05 level.

1954-1956. To comprehensively assess this relationship, we calculated the mean $\mathrm{rBC}$ concentration for all the El Niño and La Niña years for the time period 1900-1998. Mean $\mathrm{rBC}$ concentrations of $0.85 \pm 0.44 \mathrm{ng} \mathrm{g}^{-1}$ for El Niño years (50 years in total) and $0.93 \pm 0.42 \mathrm{ng} \mathrm{g}^{-1}$ for La Niña years (49 years in total) show that no significant difference is visible between the warm and cold phases of ENSO in the rBC record. Several hypotheses contribute to this lack of relationship despite drier conditions during El Niño years. First, it is well-known that the eastern side of the Andes is less influenced by ENSO modulation as the major moisture source is the Amazon Basin and not the Pacific Ocean, contrary to the western Andes (Garreaud et al., 2003; Vuille et al., 2000). Second, there is a difference in timing as the precipitation suppression induced by ENSO is more important during the wet season, whereas rBC emissions peak during the dry season due to biomass burning and limited but highly concentrated precipitation. Furthermore, if no precipitation occurs during the dry season owing to the El Niño phase of ENSO, (almost) no $\mathrm{rBC}$ will be deposited on the snow surface at the Illimani site as BC is preferentially removed from the atmosphere by wet deposition (Cape et al., 2012; Ruppel et al., 2017). Lastly, as the moisture influx from the east tends to be reduced during El Niño years, the contribution from easternorigin $\mathrm{rBC}$-enriched precipitation due to biomass burning in the Amazon Basin to the total amount of precipitation at Illimani becomes weaker.

\section{3 rBC variability over the last 1000 years}

In Fig. 5a, we present the IL-99 rBC long-term record for the last 1000 years. Higher $\mathrm{rBC}$ concentrations were observed between 1000 and $1300 \mathrm{CE}$ (mean $\pm 1 \sigma$ unless otherwise stated: $0.94 \pm 0.56 \mathrm{ng} \mathrm{g}^{-1}$ ), in agreement with the temperature maximum corresponding to the Medieval Warm Period (MWP) in the Northern Hemisphere and also previously described in the IL-99 ammonium record by Kellerhals et al. (2010a). Following the MWP, rBC concentrations slowly declined until they reached a minimum in the 18th century (mean: $0.37 \pm 0.34 \mathrm{ng} \mathrm{g}^{-1}$ ), reflecting the Little Ice Age (LIA). The lowest $\mathrm{rBC}$ concentrations were recorded around $1730 \mathrm{CE}$, following the Maunder solar minimum. After the $1730 \mathrm{CE}$ minimum, $\mathrm{rBC}$ concentrations started to rise until the present time (1900-1999 mean: $0.91 \pm 1.23 \mathrm{ng} \mathrm{g}^{-1}$ ). The similar long-term variability of $\mathrm{rBC}$ and temperature $(r=0.53, p<0.05, n=96$; Fig. 5a) provides evidence that temperature is indeed a major driving force for changing biomass burning activity, in agreement with the results for the 20th century (see Sect. 3.2). Discrepancies between the two records, particularly between 1400 and $1700 \mathrm{CE}$ when temperature anomalies were constantly negative while $\mathrm{rBC}$ concentrations displayed higher values during 1460-1550 CE and 1630-1670 CE, can most probably be related to an additional anthropogenic impact as discussed below. The IL99 cerium record (Fig. 5b; Eichler et al., 2015), used as a dust deposition tracer, shows that the MWP was characterized by dustier and drier conditions, which can indirectly explain the corresponding $\mathrm{rBC}$ peak as dry conditions favor biomass burning and lead to reduced but more concentrated wet deposition. Contrariwise, the LIA is generally marked by less dry and dusty conditions. To summarize, rBC concentrations in the Illimani record tend to be lower during 

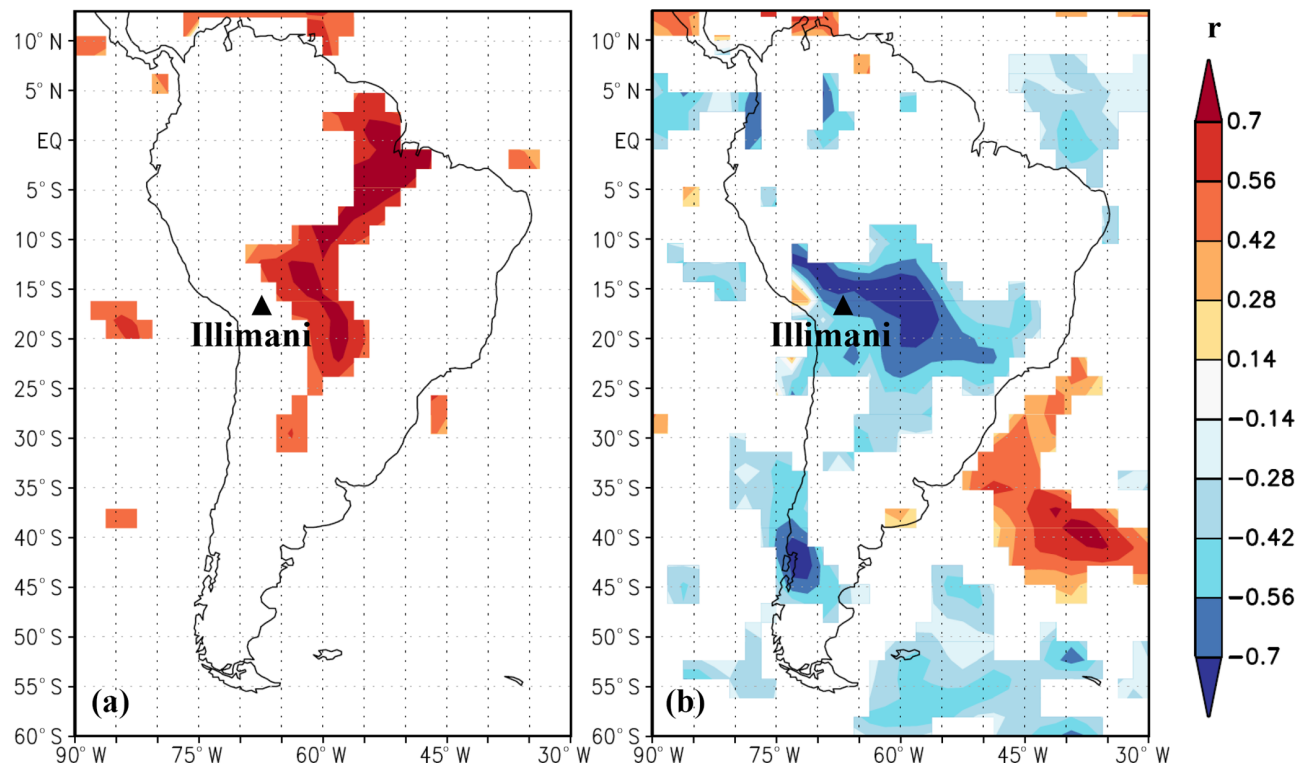

Figure 4. Spatial correlation over South America between the IL-99 rBC record and reanalyzed temperature (a) and precipitation (b) data from the NCEP-NCAR R1 dataset for the time period 1948-1998, available on the KNMI Climate Explorer (https://climexp.knmi.nl/start.cgi, last access: 28 May 2018). Data are annual means smoothed with a 5-year running mean.

periods of colder-wetter climate and higher during periods of warmer-drier climate, suggesting that rBC could be used as an indirect temperature-moisture proxy through biomass burning variations. While climate variations are driving the main trend, smaller superimposed variations could reflect an additional anthropogenic impact.

The LIA decline was interrupted by higher $\mathrm{rBC}$ concentrations during the time periods $1460-1550$ and $1630-1670 \mathrm{CE}$, potentially related to the apogee of the Inca Empire at the end of the 15th century and the Spanish colonization of Bolivia that started around 1535. Several cities were created on the Altiplano at that time (Sucre in 1538, Potosí in 1546 and La Paz in 1548). Mining activities rapidly took off and left an imprint on the IL-99 lead and copper records (Eichler et al., 2015, 2017, respectively). Between these two maxima, a drop in $\mathrm{rBC}$ concentrations can be observed in the second half of the 16th century. This could be related to a decrease in human-induced fires and/or mining activities due to either indigenous depopulation following European arrival or technical improvements in ore-smelting processes. The parallel decline in the IL-99 anthropogenic lead record after AD 1570 (and until the mid-17th century; Fig. 5c) is best explained by a technical evolution in smelting due to the introduction of an amalgamation process requiring less fuel (Eichler et al., 2015). It is therefore possible that the decline in $\mathrm{rBC}$ also reflects this technological evolution as less wood was burned in furnaces. All these variations are also corroborated by the composite charcoal record for tropical South America, showing two local maxima of fire activity surrounding a small drop superimposed on a long-term decline (Fig. 5e; Power et al., 2012). However, due to the large climatic, topographic and vegetation differences encompassed in this region, charcoal variations remained small and Power et al. (2012) could not find a clear driver (climate change or demographic collapse) for biomass burning variations in tropical South America after 1500 CE. Nevertheless, at the scale of the Americas, the same study concluded that the LIA climatic change was more important than the demographic collapse to explain the post-1500 CE biomass burning decline in the Americas (Power et al., 2012), a hypothesis supported by the IL-99 rBC record for tropical South America.

Comparable long-term trends were found in the B40 rBC and $\mathrm{NH}_{4}^{+}$ice-core records from Antarctica (Fig. 5d) with lower (higher) $\mathrm{rBC}$ and $\mathrm{NH}_{4}^{+}$concentrations during the LIA (MWP), respectively (Arienzo et al., 2017). The authors of this study suggested South American biomass burning as the main source of Antarctic $\mathrm{rBC}$ and $\mathrm{NH}_{4}^{+}$throughout the Holocene, with little modification induced by longrange transport. However, some interesting differences can be noted. First, absolute rBC concentrations are lower in the Antarctic ice cores due to remoteness from the main source regions. Second, while the timing of the MWP matches well between the two records, the transition towards the LIA was more abrupt in the B40 record, and the LIA signal displayed less variability in the Antarctic records compared to the Illimani one. Third, while the $\mathrm{B} 40 \mathrm{NH}_{4}^{+}$record did show an increase since $1900 \mathrm{CE}$, no clear increasing trend was visible in the last 250 years in the Antarctic rBC record, contrary to Illimani, thus highlighting the importance of considering transport processes when discussing $\mathrm{rBC}$ records from remote Antarctic regions. In contrast, carbon monoxide (CO) ice-core records from Antarctica representative of Southern 

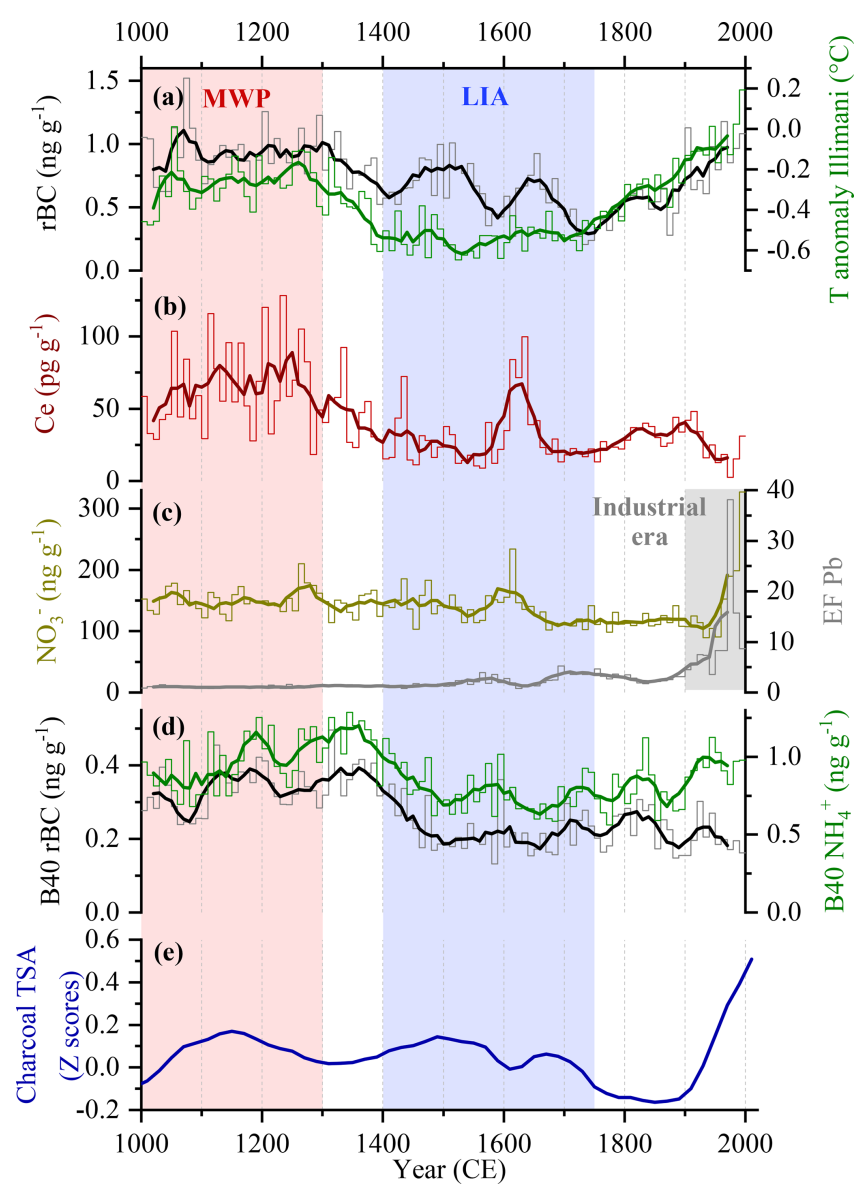

Figure 5. Comparison for the time period 1000-2000 CE between the (a) IL-99 rBC record (left scale) and temperature anomalies (right scale) inferred from the ammonium IL-99 record (Kellerhals et al., 2010a). (b) IL-99 cerium record as a dust proxy (Eichler et al., 2015); peak values from 1610 to $1630 \mathrm{CE}$ might be due to poor ice quality prone to contamination. (c) IL-99 nitrate (left scale) and lead enrichment factors (right scale) to illustrate 20th century anthropogenic impact (Eichler et al., 2015). (d) Antarctic B40 rBC (left scale) and ammonium (right scale) records (Arienzo et al., 2017) and (e) composite charcoal record ( $Z$ scores of transformed charcoal influx) for tropical South America (Power et al., 2012). For panels (a) and (d), thin lines are 10-year means and thick lines are 50-year moving means. For panels (b) and (c), thin lines are 10-year medians and thick lines are 50-year moving medians due to the presence of a few very elevated values. Panel (e) shows 20-year means. Timings of MWP (1000-1300 CE) and LIA (1400-1750 CE) are defined based on the IL-99 rBC and temperature records.

Hemisphere biomass burning follow a trend similar to the IL-99 rBC record, with a decreasing trend between 1300 and $1600 \mathrm{CE}$, a minimum in the 17th century, and an increase for the time period 1700-1900 CE (Wang et al., 2010). Divergences between $\mathrm{rBC}$ and $\mathrm{CO}$ Antarctic records might result from their different atmospheric lifetimes, implying a different spatial representativeness. $\mathrm{rBC}$ has a relatively short atmospheric lifetime from 3 to 10 days (Bond et al., 2013), while $\mathrm{CO}$ can remain in the atmosphere for weeks to months or even more than a year at the winter poles (Holloway et al., 2000).

In rBC ice-core records from the Arctic and Europe, a predominant anthropogenic contribution starting in the second half of the 19th century due to rising fossil fuel emissions was observed (Keegan et al., 2014; McConnell et al., 2007; Osmont et al., 2018; Sigl et al., 2013, 2018). At Illimani, rBC concentrations follow a long-term increasing trend since the $1730 \mathrm{CE}$ minimum. It is therefore important to investigate to what extent climate variations and human activities influenced this increase. The IL-99 dust record (Fig. 5b) reveals that this increase was not driven by dustier and drier conditions leading to enhanced deposition, as cerium concentrations remain low. Temperatures have likewise increased since $1720 \mathrm{CE}$, suggesting that the $\mathrm{rBC}$ increase is primarily driven by increasing temperatures responsible for enhanced biomass burning levels. For the time period 1730-1999 CE, the rate of increase in concentration for both the $\mathrm{rBC}$ and temperature anomaly, obtained by the linear regression of $Z$ scores calculated from 10-year means, is similar, with a slope of $0.011 \mathrm{yr}^{-1}$ (Fig. S1 in the Supplement). In contrast, the anthropogenic pollution pattern recorded in the IL-99 ice core by $\mathrm{Pb}$ and $\mathrm{NO}_{3}^{-}$(Eichler et al., 2015) shows a dramatic increase only in the second half of the 20th century, mainly due to emissions from traffic (Fig. 5c; see Fig. S2 for a higher resolution). Since this strong rise is not visible in the $\mathrm{rBC}$ record of the past 50 years, we assume that anthropogenic BC emissions from fossil fuel combustion remain minor compared to biomass-burning-related $\mathrm{BC}$ emissions. Composite charcoal records for tropical South America (Fig. 5e) also show a strong increase in fire activity during the 20th century, explained by enhanced deforestation (Power et al., 2012). Thus, we cannot exclude that, in the 20th century, a certain fraction of the biomass burning increase reflected by the $\mathrm{rBC}$ record not only originates from rising temperatures but could also be the result of the expansion of deforestation. However, a detailed assessment of the relative impact of those two factors cannot be obtained given the lack of accurate statistics before the satellite measurement era. The Food and Agriculture Organization (FAO) of the United Nations has been monitoring forested areas since 1947, but many inconsistencies occurred in the first reports due to high uncertainties in estimating forested areas in remote regions and changing definitions and methodologies between the subsequent reports, thus making extensive comparison impossible (Steininger et al., 2001).

\subsection{Evidence of a Holocene Climatic Optimum dry period}

The relationship between $\mathrm{rBC}$ concentrations and regional temperature-moisture variations extends further back in time through the entire Holocene. The bottommost part of the IL99 ice core, between 11000 and $10000 \mathrm{BCE}$, shows low 


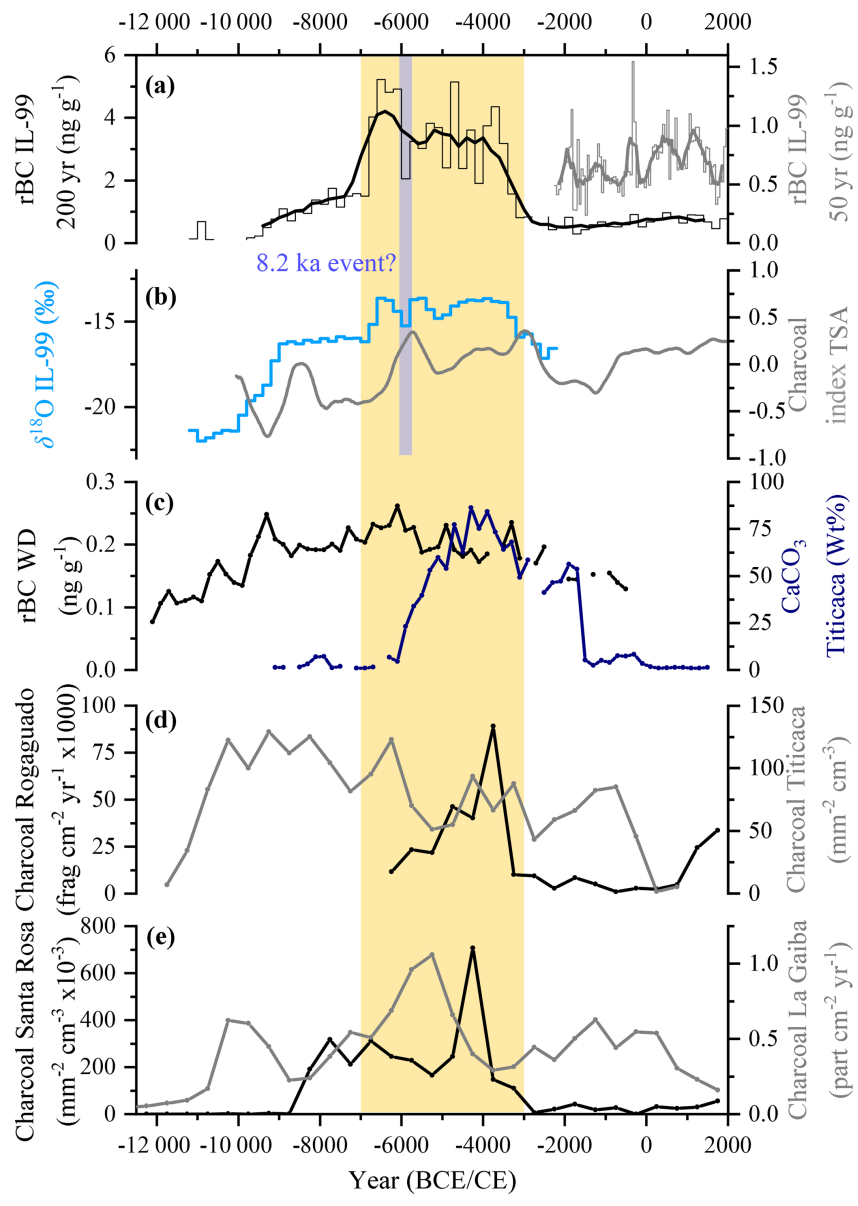

Figure 6. Evidence of a dry period corresponding to the Holocene Climatic Optimum (HCO, yellow bar) in the IL-99 ice core and in other paleoclimatic reconstructions. (a) IL-99 rBC record, 200-year mean (left scale) and 50-year mean (right scale). Thick lines are 5 -point moving means. The blue bar represents the cold-wet reversal potentially related to the $8.2 \mathrm{ka}$ event. Gaps in the IL-99 rBC record are due to lack of available ice-core material due to previous samplings. (b) IL-99 $\delta^{18} \mathrm{O}$ record (Sigl et al., 2009; left scale) and composite charcoal record for tropical South America (Marlon et al., 2013; right scale, 20-year mean with a 500-year smoothing). (c) $\mathrm{rBC}$ record from the West Antarctic Ice Sheet Divide (WD) ice core, Antarctica (Arienzo et al., 2017; left scale), and calcium carbonate weight percent $\left(\mathrm{CaCO}_{3} \mathrm{wt} \%\right.$, right scale) recorded in a sediment core from Lake Titicaca as a proxy for lake-level variations. A higher percentage indicates a lower lake level (drier conditions) as salinity increases in the lake, leading to the precipitation of $\mathrm{CaCO}_{3}$ and its deposition in the sediments (Baker et al., 2001). Data are 200-year means. (d) Charcoal records from Lake Rogaguado (Brugger et al., 2016; left scale) and Lake Titicaca (Paduano et al., 2003; right scale). (e) Charcoal records from Lake Santa Rosa (Urrego, 2006; left scale) and Laguna La Gaiba (Power et al., 2016; right scale). Data in panels (d)-(e) are 500-year means.

rBC concentrations (Fig. 6a) as well as low $\delta^{18} \mathrm{O}$ values (Fig. 6b), indicative of a cold and wet climate corresponding to the Younger Dryas cold period in the Northern Hemi- sphere. Over the Bolivian Altiplano, wet conditions were evidenced by higher shorelines of Lake Titicaca between 11000 and $9500 \mathrm{BCE}$, inferred from benthic and planktonic diatom fractions (Baker et al., 2001), while cold conditions were suggested by glacier advances in the Cordillera Real between 11000 and 9000 BCE during the "Coipasa" humid phase (Zech et al., 2007). This illustrates that the Younger Dryas was not dry on a global scale despite increasing dustiness in Greenland ice-core records (Mayewski et al., 1993). The establishment of warmer and drier conditions corresponding to the onset of the Holocene occurred between 10000 and $9000 \mathrm{BCE}$ as evidenced by a pronounced increase $\left(+5.5 \%\right.$ ) in the $\delta^{18} \mathrm{O}$ record (Sigl et al., 2009), comparable to the $+5.4 \%$ increase in the nearby Sajama ice core (Thompson et al., 1998), and was followed by a stabilization around $-16 \%$ o between 9000 and 7000 BCE. Around $7000 \mathrm{BCE}$, warm and dry conditions abruptly prevailed as indicated by a further increase in $\delta^{18} \mathrm{O}(+2 \%)$. These conditions that lasted until $3500 \mathrm{BCE}$ correspond to the Holocene Climatic Optimum (HCO). The HCO period is marked by the highest $\mathrm{rBC}$ concentrations of the whole 13000 -year record (rBC mean 7000-3500 BCE: $2.97 \pm 1.77 \mathrm{ng} \mathrm{g}^{-1}$ ). A lower accumulation rate, induced by drier conditions, might partially explain higher rBC concentrations. However, it cannot be the only driving force, as the highest $\mathrm{rBC}$ concentrations were recorded between 7000 and $6000 \mathrm{BCE}$ and not between 6000 and $3000 \mathrm{BCE}$, despite an accumulation rate 3 times lower in the second time period. Numerous studies have already shown evidence of a dry HCO in Bolivia, although timings might slightly differ between regions and ecosystems. The lowest Lake Titicaca level (Fig. 6c) occurred between 6000 and $3500 \mathrm{BCE}$ in a context of maximal aridity over the Bolivian Altiplano (Baker et al., 2001). The charcoal record from Lake Titicaca (Fig. 6d) shows a broader maximum from 10000 to 1000 BCE (Paduano et al., 2003). Pollen data from the same record suggest a dry period lasting from 7000 to $1100 \mathrm{BCE}$ and peaking between 4000 and 2000 BCE. Reduced pollen concentrations in the Sajama ice core between 6000 and $3000 \mathrm{BCE}$ are also indicative of a drier climate (Reese et al., 2013). Among charcoal records, the best agreement with the IL- $99 \mathrm{rBC}$ record is observed for those located in the Bolivian lowlands. In this region, fire activity was high between 6100 and $3800 \mathrm{BCE}$ in the Llanos de Moxos (Fig. 6d; Lake Rogaguado; Brugger et al., 2016), between 6000 and 5000 BCE in the Chiquitano SDTF (Fig. 6e; Laguna La Gaiba, Power et al., 2016; although this site is located quite far from Illimani), and between 8000 and $4000 \mathrm{BCE}$ around Lake Santa Rosa (Fig. 6e, Urrego, 2006). Composite charcoal records for tropical South America (Fig. 6b) show elevated biomass burning levels between 6000 and 2500 BCE (Marlon et al., 2013) but cover a much larger area, which is not only representative of the Illimani source region. In the West Antarctic Ice Sheet Divide (WD) ice core, the highest $\mathrm{rBC}$ deposition occurred during the midHolocene from 6000 to 4000 BCE (Fig. 6c; Arienzo et al., 
2017). The HCO maximum appears broader than in the IL99 ice core, probably due to a larger catchment area and the influence of long-range transport processes.

Antiphase hydroclimate variations have been detected in the northern South American tropics, as shown by the titanium and iron records from the Cariaco Basin, Venezuela (Haug et al., 2001). Dry conditions prevailed during the Younger Dryas, while the HCO, dated between 8500 and $3400 \mathrm{BCE}$, experienced the wettest conditions of the last 14000 years in this region. The Late Holocene was then characterized by a return to a drier climate. Similarly, wetter (drier) conditions were observed during the MWP (LIA). This antiphasing between the northern and southern South American tropics has been best explained by latitudinal variations of the Intertropical Convergence Zone (ITCZ) (Haug et al., 2001; Arienzo et al., 2017). During the HCO, in a context of a low austral summer insolation due to orbital forcing, the ICTZ was shifted north, leading to more precipitation in the Cariaco region and a weaker South American summer monsoon (SASM) responsible for drier conditions in the southern South American tropics, as evidenced in the Illimani record. Towards the Late Holocene, increasing (decreasing) insolation seasonality in the Southern (Northern) Hemisphere may have resulted in a progressive southward shift of the ITCZ and a strengthening of the SASM, inducing wetter conditions over the southern South American tropics but drier conditions in the northern South American tropics. A similar conclusion can be drawn for the LIA (Arienzo et al., 2017).

Throughout the last 4000 years, $\mathrm{rBC}$ concentrations in the IL-99 ice core showed a much lower level (Fig. 6a). Between $2250 \mathrm{BCE}$ and $100 \mathrm{CE}, \mathrm{rBC}$ concentrations remained low (mean: $0.60 \pm 0.37 \mathrm{ng} \mathrm{g}^{-1}$ ) except for a peak value of $1.55 \mathrm{ng} \mathrm{g}^{-1}$ around $300 \mathrm{BCE}$. Brugger et al. (2016) also observed a minimum of burning in a lake sediment charcoal record from the Bolivian Amazonian lowlands around 2000 BP (Fig. 6d) in response to forest expansion due to increased moisture availability. After $100 \mathrm{CE}$, rBC concentrations started to rise and remained higher for the time period 150-650 CE (mean: $0.86 \pm 0.32 \mathrm{ng} \mathrm{g}^{-1}$ ) but declined again and stayed low between 750 and 1000 CE (mean: $0.65 \pm 0.41 \mathrm{ng} \mathrm{g}^{-1}$ ). This in line with the temperature reconstruction from Illimani, showing slightly lower temperatures between approximately 700 and $1000 \mathrm{CE}$ compared to the time period before (Kellerhals et al., 2010a).

In addition to the long-term trends described above, a particular event in the rBC IL-99 record is of special interest. Around $6000 \mathrm{BCE}$, a dip in the $\delta^{18} \mathrm{O}$ record (Fig. 6b) suggests an abrupt centennial-scale return to cooler and wetter conditions, potentially related to the Northern Hemisphere $8.2 \mathrm{ka}$ cold event detected in Greenland ice cores (Alley et al., 1997; Thomas et al., 2007) and revealing that its impacts were also apparent in the southern South American tropics. According to the current consensus, this cooling was caused by the Laurentide ice cap collapse that generated enormous freshwater fluxes into the North Atlantic Ocean (Matero et al., 2017). A concurrent drop in the rBC concentration $\sim 6000 \mathrm{BCE}$ (Fig. 6a) suggests that this climate anomaly also led to reduced levels of biomass burning.

\section{Conclusions}

Refractory black carbon (rBC) was analyzed in an ice core from Illimani (Bolivian Andes), spanning the entire Holocene back to the last deglaciation 13000 years ago. The high-resolution signal in the upper part of the ice cores revealed a strong seasonal pattern for $\mathrm{rBC}$, with peak values during the dry season and low concentrations during the wet season as a result of the seasonality of emission sources and precipitation. Significant correlations were found between the 20th century $\mathrm{rBC}$ record and reanalyzed temperatureprecipitation datasets from the Amazon Basin, particularly with regions located in eastern Bolivia and western Brazil experiencing high levels of biomass burning. The modulation of the seasonality by ENSO processes was shown to be weak due to the site location in the eastern Andes. The long-term $\mathrm{rBC}$ record was shown to behave like an indirect regional temperature-moisture proxy through biomass burning variations, with low values during cold-wet periods such as the Younger Dryas and the Little Ice Age and higher concentrations during warm-dry periods such as the Holocene Climatic Optimum and the Medieval Warm Period. These findings are supported by an array of regional paleoclimate reconstructions and by Antarctic $\mathrm{rBC}$ ice-core records thought to represent South American biomass burning emissions, which are primarily controlled by insolation-driven latitudinal changes of the Intertropical Convergence Zone. Evidence of a cold-wet reversal induced by the $8.2 \mathrm{ka}$ event was detected in the Illimani ice core. Our work confirms that most of the Northern Hemisphere climate variations throughout the Holocene also left an imprint in the tropical Andes and that opposite hydroclimate variations were observed between the northern and southern South American tropics. Lastly, the rise in $\mathrm{rBC}$ concentrations since $1730 \mathrm{CE}$ seems predominantly driven by increased biomass burning levels due to higher temperatures and more intensive deforestation in the last decades, which contrasts with global biomass burning reconstructions based on charcoal data, while the contribution from fossil fuel $\mathrm{rBC}$ emissions remains minor.

Data availability. The $\mathrm{rBC}$ data are available at the US National Oceanic and Atmospheric Administration (NOAA) data center for paleoclimate (ice-core sites) at the following address: http://www.ncdc.noaa.gov/data-access/paleoclimatology-data/ datasets/ice-core (Osmont, 2019). 
Supplement. The supplement related to this article is available online at: https://doi.org/10.5194/cp-15-579-2019-supplement.

Author contributions. DO sampled the Illimani ice core, carried out SP2 measurements, analyzed the data and wrote the paper. MiS helped with ice cutting, $\mathrm{rBC}$ analyses and data interpretation. AE and TMJ assisted with the data interpretation. MaS designed and led the project and supervised the paper writing.

Competing interests. The authors declare that they have no conflict of interest.

Acknowledgements. We acknowledge funding from the Swiss National Science Foundation through the Sinergia project "Paleo fires from high-alpine ice cores" (CRSII2_154450/1). The authors would like to thank Susanne Haselbeck for helping with the SP2 measurements, Sabina Brütsch for ion chromatography and water stable isotope analyses, Thomas Kellerhals for his previous work on the Illimani ice core, Robin Modini and Jinfeng Yuan for their technical assistance in calibrating the SP2, Sandra Brugger, Jennifer Marlon and Mitchell Power for the charcoal data, and the team members of the 1999 drilling campaign at Illimani.

Review statement. This paper was edited by Anne-Laure Daniau and reviewed by two anonymous referees.

\section{References}

Aceituno, P.: On the Functioning of the Southern Oscillation in the South American Sector, Part I: Surface Climate, Mon. Weather Rev., 116, 505-524, 1988.

Alley, R. B., Mayewski, P. A., Sowers, T., Stuiver, M., Taylor, K. C., and Clark, P. U.: Holocene climatic instability: A prominent, widespread event $8200 \mathrm{yr}$ ago, Geology, 25, 483-486, 1997.

Arienzo, M. M., McConnell, J. R., Murphy, L. N., Chellman, N., Das, S., Kipfstuhl, S., and Mulvaney, R.: Holocene black carbon in Antarctica paralleled Southern Hemisphere climate, J. Geophys. Res.-Atmos., 122, 6713-6728, 2017.

Artaxo, P., Fernandes, E. T., Martins, J. V., Yamasoe, M. A., Hobbs, P. V., Maenhaut, W., Longo, K. M., and Castanho, A.: Largescale aerosol source apportionment in Amazonia, J. Geophys. Res., 103, 31837-31847, 1998.

Baker, P. A., Seltzer, G. O., Fritz, S. C., Dunbar, R. B., Grove, M. J., Tapia, P. M., Cross, S. L., Rowe, H. D., and Broda, J.P.: The history of South American tropical precipitation for the past 25000 years, Science, 291, 640-643, 2001.

Bond, T. C., Doherty, S. J., Fahey, D. W., Forster, P. M., Berntsen, T., DeAngelo, B. J., Flanner, M. G., Ghan, S., Karcher, B., Koch, D., Kinne, S., Kondo, Y., Quinn, P. K., Sarofim, M. C., Schultz, M. G., Schulz, M., Venkataraman, C., Zhang, H., Zhang, S., Bellouin, N., Guttikunda, S. K., Hopke, P. K., Jacobson, M. Z., Kaiser, J. W., Klimont, Z., Lohmann, U., Schwarz, J. P., Shindell, D., Storelvmo, T., Warren, S. G., and Zender, C. S.: Bound- ing the role of black carbon in the climate system: A scientific assessment, J. Geophys. Res.-Atmos., 118, 5380-5552, 2013.

Bonnaveira, H.: Etude des phénomènes de dépôt et post-dépôt de la neige andine sur un site tropical d'altitude (Illimani-Bolivie$6340 \mathrm{~m}$ ) en vue de l'interprétation d'une carotte de glace, Ph.D. Thesis, Université Joseph Fourier, Grenoble, France, 2004.

Bowman, D. M. J. S., Balch, J. K., Artaxo, P., Bond, W. J., Carlson, J. M., Cochrane, M. A., D’Antonio, C. M., DeFries, R. S., Doyle, J. C., Harrison, S. P., Johnston, F. H., Keeley, J. E., Krawchuk, M. A., Kull, C. A., Marston, J. B., Mortiz, M. A., Prentice, I. C., Roos, C. I., Scott, A. C., Swetnam, T. W., van der Werf, G. R., and Pyne, S. J.: Fire in the Earth System, Science, 324, 481-484, 2009.

Bowman, D. M. J. S., Balch, J., Artaxo, P., Bond, W. J., Cochrane, M. A., D'Antonio, C. M., DeFries, R., Johnston, F. H., Keeley, J. E., Krawchuk, M. A., Kull, C. A., Mack, M., Moritz, M. A., Pyne, S., Roos, C. I., Scott, A. C., Sodhi, N. S., and Swetnam, T. W.: The human dimension of fire regimes on Earth, J. Biogeogr., 38, 2223-2236, 2011.

Brugger, S. O., Gobet, E., van Leeuwen, J. F. N., Ledru, M.-P., Colombaroli, D., van der Knaap, W. O., Lombardo, U., EscobarTorrez, K., Finsinger, W., Rodrigues, L., Giesche, A., Zarate, M., Veit, H., and Tinner, W.: Long-term man-environment interactions in the Bolivian Amazon: 8000 years of vegetation dynamics, Quaternary Sci. Rev., 132, 114-128, 2016.

Cape, J. N., Coyle, M., and Dumitrean, P.: The atmospheric lifetime of black carbon, Atmos. Environ., 59, 256-263, 2012.

Chen, Y., Morton, D. C., Jin, Y., Collatz, G. J., Kasibhatla, P. S., van der Werf, G. R., DeFries, R. S., and Randerson, J. T.: Long-term trends and interannual variability of forest, savanna and agricultural fires in South America, Carbon Manag., 4, 617-638, 2013.

Cochrane, M. A.: Fire science for rainforests, Nature, 421, 913-919, 2003.

Cochrane, M. A., Alencar, A., Schulze, M. D., Souza Jr., C. M., Nepstad, D. C., Lefebvre, P., and Davidson, E. A.: Positive feedbacks in the fire dynamic of closed canopy tropical forests, Science, 284, 1832-1835, 1999.

Correia, A., Freydier, R., Delmas, R. J., Simões, J. C., Taupin, J.D., Dupré, B., and Artaxo, P.: Trace elements in South America aerosol during 20th century inferred from a Nevado Illimani ice core, Eastern Bolivian Andes (6350 m a.s.1.), Atmos. Chem. Phys., 3, 1337-1352, https://doi.org/10.5194/acp-3-1337-2003, 2003.

De Angelis, M., Simões, J., Bonnaveira, H., Taupin, J.-D., and Delmas, R. J.: Volcanic eruptions recorded in the Illimani ice core (Bolivia): 1918-1998 and Tambora periods, Atmos. Chem. Phys., 3, 1725-1741, https://doi.org/10.5194/acp-3-1725-2003, 2003.

Eichler, A., Schwikowski, M., Gäggeler, H. W., Furrer, V., Synal, H.-A., Beer, J., Saurer, M., and Funk, M.: Glaciochemical dating of an ice core from upper Grenzgletscher (4200 m a.s.1.), J. Glaciol., 46, 507-515, 2000.

Eichler, A., Gramlich, G., Kellerhals, T., Tobler, L., and Schwikowski, M.: Pb pollution from leaded gasoline in South America in the context of a 2000-year metallurgical history, Sci. Adv., 1, e1400196, https://doi.org/10.1126/sciadv.1400196, 2015.

Eichler, A., Gramlich, G., Kellerhals, T., Tobler, L., Rehren, Th., and Schwikowski, M.: Ice-core evidence of earliest extensive 
copper metallurgy in the Andes 2700 years ago, Sci. Rep., 7, 41855, https://doi.org/10.1038/srep41855, 2017.

Fischer, H., Schüpbach, S., Gfeller, G., Bigler, M., Rothlisberger, R., Erhardt, T., Stocker, T. F., Mulvaney, R., and Wolff, E.: Millennial changes in North American wildfire and soil activity over the last glacial cycle, Nat. Geosci., 8, 723-728, 2015.

Foley, J. A., Botta, A., and Coe, M. T.: El Niño-Southern oscillation and the climate, ecosystems and rivers of Amazonia, Global Biogeochem. Cy., 16, 1132, https://doi.org/10.1029/2002GB001872, 2002.

Garreaud, R. D. and Aceituno, P.: Interannual rainfall variability over the South American Altiplano, J. Clim., 14, 2779- 2789, 2001.

Garreaud, R., Vuille, M., and Clement, A. C.: The climate of the Altiplano: observed current conditions and mechanisms of past changes, Palaeogeogr. Palaeocl., 194, 5-22, 2003.

Garreaud, R. D., Vuille, M., Compagnucci, R., and Marengo, J.: Present-day South American climate, Palaeogeogr. Palaeocl., 281, 180-195, 2009.

Giglio, L., Randerson, J. T., and van der Werf, G. R.: Analysis of daily, monthly, and annual burned area using the fourthgeneration global fire emissions database (GFED4), J. Geophys. Res.-Biogeo., 118, 317-328, 2013.

Ginot, P., Stampfli, F., Stampfli, D., Schwikowski, M., and Gäggeler, H. W.: FELICS, a new ice core drilling system for high-altitude glaciers, Mem. Natl. Inst. Polar Res. Spec. Issue, $56,38-48,2002 a$.

Ginot, P., Schwikowski, M., Schotterer, U., Stichler, W., Gäggeler, H. W., Francou, B., Gallaire, R., and Pouyaud, B.: Potential for climate variability reconstruction from Andean glaciochemical records, Ann. Glaciol., 35, 443-450, 2002b.

Haug, G. H., Hughen, K. A., Sigman, D. M., Peterson, L. C., and Röhl, U.: Southward Migration of the Intertropical Convergence Zone Through the Holocene, Science, 293, 1304-1308, 2001.

Holloway, T., Levy II, H., and Kasibhatla, P.: Global distribution of carbon monoxide, J. Geophys. Res., 105, 12123-12147, 2000.

Jenk, T. M., Szidat, S., Schwikowski, M., Gäggeler, H. W., Brütsch, S., Wacker, L., Synal, H.-A., and Saurer, M.: Radiocarbon analysis in an Alpine ice core: record of anthropogenic and biogenic contributions to carbonaceous aerosols in the past (1650-1940), Atmos. Chem. Phys., 6, 5381-5390, https://doi.org/10.5194/acp6-5381-2006, 2006.

Kaspari, S. D., Schwikowski, M., Gysel, M., Flanner, M. G., Kang, S., Hou, S., and Mayewski, P. A.: Recent Increase in Black Carbon Concentrations from a Mt. Everest Ice Core Spanning 1860-2000 AD, Geophys. Res. Lett., 38, L04703, https://doi.org/10.1029/2010GL046096, 2011.

Keegan, K. M., Albert, M. R., McConnell, J. R., and Baker, I.: Climate change and forest fires synergistically drive widespread melt events of the Greenland Ice Sheet, P. Natl. Acad. Sci. USA, 111, 7964-7967, 2014.

Kehrwald, N., Whitlock, C., Barbante, C., Brovkin, V., Daniau, A.L., Kaplan, J. O., Marlon, J. R., Power, M. J., Thonicke, K., and van der Werf, G. R.: Fire research: linking past, present, and future data, EOS, 94, 421-422, 2013.

Kellerhals, T., Brütsch, S., Sigl, M., Knüsel, S., Gäggeler, H. W., and Schwikowski, M.: Ammonium concentration in ice cores: A new proxy for regional temperature reconstruction?, J. Geophys.
Res., 115, D16123, https://doi.org/10.1029/2009JD012603, 2010a.

Kellerhals, T., Tobler, L., Brütsch, S., Sigl, M., Wacker, L., Gäggeler, H. W., and Schwikowski, M.: Thallium as a tracer for preindustrial volcanic eruptions in an ice core record from Illimani, Bolivia, Environ. Sci. Technol., 44, 888-893, 2010 b.

Kloster, S., Mahowald, N. M., Randerson, J. T., Thornton, P. E., Hoffman, F. M., Levis, S., Lawrence, P. J., Feddema, J. J., Oleson, K. W., and Lawrence, D. M.: Fire dynamics during the 20th century simulated by the Community Land Model, Biogeosciences, 7, 1877-1902, https://doi.org/10.5194/bg-7-18772010, 2010.

Knüsel, S., Ginot, P., Schotterer, U., Schwikowski, M., Gäggeler, H. W., Francou, B., Petit, J. R., Simões, J. C., and Taupin, J. D.: Dating of two nearby ice cores from the Illimani, Bolivia, J. Geophys. Res., 108, 4181, https://doi.org/10.1029/2001JD002028, 2003.

Knüsel, S., Brütsch, S., Henderson, K., Palmer, A. S., and Schwikowski, M.: ENSO signals of the 20th century in an ice core from Nevado Illimani, Bolivia, J. Geophys. Res., 110, D01102, https://doi.org/10.1029/2004JD005420, 2005.

Lavanchy, V. M. H., Gäggeler, H. W., Schotterer, U., Schwikowski, M., and Baltensperger, U.: Historical record of carbonaceous particle concentrations from a European high-alpine glacier (Colle Gnifetti, Switzerland), J. Geophys. Res., 104, 21227-21236, 1999.

Legrand, M., McConnell, J., Fischer, H., Wolff, E. W., Preunkert, S., Arienzo, M., Chellman, N., Leuenberger, D., Maselli, O., Place, P., Sigl, M., Schüpbach, S., and Flannigan, M.: Boreal fire records in Northern Hemisphere ice cores: a review, Clim. Past, 12, 2033-2059, https://doi.org/10.5194/cp-12-2033-2016, 2016.

Lim, S., Faïn, X., Ginot, P., Mikhalenko, V., Kutuzov, S., Paris, J.-D., Kozachek, A., and Laj, P.: Black carbon variability since preindustrial times in the eastern part of Europe reconstructed from Mt. Elbrus, Caucasus, ice cores, Atmos. Chem. Phys., 17, 3489-3505, https://doi.org/10.5194/acp-17-3489-2017, 2017.

Marlon, J. R., Bartlein, P. J., Carcaillet, C., Gavin, D. G., Harrison, S. P., Higuera, P. E., Joos, F., Power, M. J., and Prentice, I. C.: Climate and human influences on global biomass burning over the past two millennia, Nat. Geosci., 1, 697-702, 2008.

Marlon, J. R., Bartlein, P. J., Daniau, A.-L., Harrison, S. P., Maezumi, S. Y., Power, M. J., Tinner, W., and Vannière, B.: Global biomass burning: a synthesis and review of Holocene paleofire records and their controls, Quaternary Sci. Rev., 65, 5-25, 2013.

Matero, I. S. O., Gregoire, L. J., Ivanovic, R. F., Tindall, J. C., and Haywood, A. M.: The 8.2 ka cooling event caused by Laurentide ice saddle collapse, Earth Planet. Sc. Lett., 473, 205-214, 2017.

Mayewski, P. A., Meeker, L. D., Whitlow, S., Twickler, M. S., Morrison, M. C., Alley, R. B., Bloomfield, P., and Taylor, K.: The atmosphere during the Younger Dryas, Science, 261, 195-197, 1993.

McConnell, J. R., Edwards, R., Kok, G. L., Flanner, M. G., Zender, C. S., Saltzman, E. S., Banta, J. R., Pasteris, D. R., Carter, M. M., and Kahl, J. D. W.: 20th-century industrial black carbon emissions altered arctic climate forcing, Science, 317, 1381-1384, 2007.

Molina, L. T., Gallardo, L., Andrade, M., Baumgardner, D., BorborCórdova, M., Bórquez, R., Casassa, G., Cereceda-Balic, F., Daw- 
idowski, L., Garreaud, R., Huneeus, N., Lambert, F., McCarty, J. L., Mc Phee, J., Mena-Carrasco, M., Raga, G. B., Schmitt, C., and Schwarz, J. P.: Pollution and its impacts on the South American cryosphere, Earth's Future, 3, 345-369, 2015.

Montellano, A. R.: Cartografía multitemporal de quemas e incendios forestales en Bolivia: Detección y validación post-incendio (Multitemporal mapping forest fires and burn in Bolivia: detection and post-fire validation), Ecología en Bolivia, 47, 53-71, 2012.

Mouillot, F. and Field, C.: Fire history and the global carbon budget: a $1^{\circ} \times 1^{\circ}$ fire history reconstruction for the 20th century, Glob. Change Biol., 11, 398-420, 2005.

Osmont, D., Wendl, I. A., Schmidely, L., Sigl, M., Vega, C. P., Isaksson, E., and Schwikowski, M.: An 800-year highresolution black carbon ice core record from Lomonosovfonna, Svalbard, Atmos. Chem. Phys., 18, 12777-12795, https://doi.org/10.5194/acp-18-12777-2018, 2018.

Osmont, D.: Illimani, Bolivia, Holocene ice core black carbon data, available at: http://www.ncdc.noaa.gov/data-access/ paleoclimatology-data/datasets/ice-core, last access: 27 March 2019.

Paduano, G. M., Bush, M. B., Baker, P. A., Fritz, S. C., and Seltzer, G. O.: A Vegetation and Fire History of Lake Titicaca since the Last Glacial Maximum, Palaeogeogr. Palaeocl., 194, 259-279, 2003.

Power, M. J., Mayle, F. E., Bartlein, P. J., Marlon, J. R., Anderson, R. S., Behling, H., Brown, K. J., Carcaillet, C., Colombaroli, D., Gavin, D. G., Hallett, D. J., Horn, S. P., Kennedy, L. M., Lane, C. S., Long, C. J., Moreno, P. I., Paitre, C., Robinson, G., Taylor, Z., and Walsh, M. K.: Climatic control of the biomass-burning decline in the Americas after AD 1500, Holocene, 23, 3-13, 2012.

Power, M. J., Whitney, B. S., Mayle, F. E., Neves, D. M., de Boer, E. J., and Maclean, K. S.: Fire, climate and vegetation linkages in the Bolivian Chiquitano seasonally dry tropical forest, Philos. T. Roy. Soc. B, 371, 20150165, https://doi.org/10.1098/rstb.2015.0165, 2016.

Petzold, A., Ogren, J. A., Fiebig, M., Laj, P., Li, S.-M., Baltensperger, U., Holzer-Popp, T., Kinne, S., Pappalardo, G., Sugimoto, N., Wehrli, C., Wiedensohler, A., and Zhang, X.-Y.: Recommendations for reporting "black carbon" measurements, Atmos. Chem. Phys., 13, 8365-8379, https://doi.org/10.5194/acp13-8365-2013, 2013.

Reese, C. A., Liu, K. B., and Thompson, L. G.: An ice-core pollen record showing vegetation response to Late-glacial and Holocene climate changes at Nevado Sajama, Bolivia, Ann. Glaciol., 54, 183-190, 2013.

Ronchail, J. and Gallaire, R.: ENSO and rainfall along the Zongo valley (Bolivia) from the Altiplano to the Amazon basin, Int. J. Climatol., 26, 1223-1236, 2006.

Ronchail, J., Cochonneau, G., Molinier, M., Guyot, J., Goretti De Miranda, A., Guimarães, V., and Oliveira, E.: Interannual rainfall variability in the Amazon basin and sea-surface temperatures in the equatorial Pacific and the tropical Atlantic Oceans, Int. J. Climatol., 22, 1663-1686, 2002.

Ruppel, M. M., Soares, J., Gallet, J.-C., Isaksson, E., Martma, T., Svensson, J., Kohler, J., Pedersen, C. A., Manninen, S., Korhola, A., and Ström, J.: Do contemporary (1980-2015) emissions determine the elemental carbon deposition trend at Holtedahl- fonna glacier, Svalbard?, Atmos. Chem. Phys., 17, 12779-12795, https://doi.org/10.5194/acp-17-12779-2017, 2017.

Schmitt, C. G., All, J. D., Schwarz, J. P., Arnott, W. P., Cole, R. J., Lapham, E., and Celestian, A.: Measurements of light-absorbing particles on the glaciers in the Cordillera Blanca, Peru, The Cryosphere, 9, 331-340, https://doi.org/10.5194/tc-9-331-2015, 2015.

Schultz, M. G., Heil, A., Hoelzemann, J. J., Spessa, A., Thonicke, K., Goldammer, J. G., Held, A. C., Pereira, J. M. C., and van het Bolscher, M.: Global wildland fire emissions from 1960 to 2000, Global Biogeochem. Cy., 22, GB2002, https://doi.org/10.1029/2007GB003031, 2008.

Schwarz, J. P., Gao, R. S., Fahey, D. W., Thomson, D. S., Watts, L. A., Wilson, J. C., Reeves, J. M., Darbeheshti, M., Baumgardner, D. G., Kok, G. L., Chung, S. H., Schulz, M., Hendricks, J., Lauer, A., Karcher, B., Slowik, J. G., Rosenlof, K. H., Thompson, T. L., Langford, A. O., Loewenstein, M., and Aikin, K. C.: Single-particle measurements of midlatitude black carbon and light-scattering aerosols from the boundary layer to the lower stratosphere, J. Geophys. Res., 111, D16207, https://doi.org/10.1029/2006JD007076, 2006.

Sigl, M., Jenk, T. M., Kellerhals, T., Szidat, S., Gäggeler, H. W., Wacker, L., Synal, H.-A., Boutron, C., Barbante, C., Gabrieli, J., and Schwikowski, M.: Instruments and Methods Towards radiocarbon dating of ice cores, J. Glaciol., 55, 985-996, 2009.

Sigl, M., McConnell, J. R., Layman, L., Maselli, O., McGwire, K., Pasteris, D., Dahl-Jensen, D., Steffensen, J. P., Vinther, B., Edwards, R., Mulvaney, R., and Kipfstuhl, S.: A new bipolar ice core record of volcanism from WAIS Divide and NEEM and implications for climate forcing of the last 2000 years, J. Geophys Res.-Atmos., 118, 1151-1169, 2013.

Sigl, M., Abram, N. J., Gabrieli, J., Jenk, T. M., Osmont, D., and Schwikowski, M.: 19th century glacier retreat in the Alps preceded the emergence of industrial black carbon deposition on high-alpine glaciers, The Cryosphere, 12, 3311-3331, https://doi.org/10.5194/tc-12-3311-2018, 2018.

Steininger, M. K, Tucker, C. J., Townshend, J. R. G., Killeen, T. J., Desch, A., Bell, V., and Ersts, P.: Tropical deforestation in the Bolivian Amazon, Environ. Conserv., 28, 127-134, 2001.

Stephens, M., Turner, N., and Sandberg, J.: Particle identification by laser-induced incandescence in a solid-state laser cavity, Appl. Optics, 42, 3726-3736, 2003.

Thomas, E. R., Wolff, E. W., Mulvaney, R., Steffensen, J. P., Johnsen, S. J., Arrowsmith, C., White, J. W. C., Vaughn, B., and Popp, T.: The 8.2 ka event from Greenland ice cores, Quaternary Sci. Rev., 26, 70-81, 2007.

Thompson, L. G., Davis, M. E., Mosley-Thompson, E., Sowers, T. A., Henderson, K. A., Zagorodnov, V. S., Lin, P.-N., Mikhalenko, V. N., Campen, R. K., Bolzan, J. F., Cole-Dai, J., and Francou, B.: A 25,000-year tropical climate history from Bolivian ice cores, Science, 282, 1858-1864, 1998.

Urrego, D. H.: Long-term vegetation and climate change in Western Amazonia, PhD Dissertation, Department of Biological Sciences, Florida Institute of Technology, Melbourne, USA, 278 pp., 2006.

van der Werf, G. R., Randerson, J. T., Giglio, L., Collatz, G. J., Mu, M., Kasibhatla, P. S., Morton, D. C., DeFries, R. S., Jin, Y., and van Leeuwen, T. T.: Global fire emissions and the contribution of deforestation, savanna, forest, agricultural, and 
peat fires (1997-2009), Atmos. Chem. Phys., 10, 11707-11735, https://doi.org/10.5194/acp-10-11707-2010, 2010.

van Marle, M. J. E., Field, R. D., van der Werf, G. R., Estrada de Wagt, I. A., Houghton, R. A., Rizzo, L. V., Artaxo, P., and Tsigaridis, K.: Fire and deforestation dynamics in Amazonia (19732014), Global Biogeochem. Cy., 31, 24-38, 2017 a.

van Marle, M. J. E., Kloster, S., Magi, B. I., Marlon, J. R., Daniau, A.-L., Field, R. D., Arneth, A., Forrest, M., Hantson, S., Kehrwald, N. M., Knorr, W., Lasslop, G., Li, F., Mangeon, S., Yue, C., Kaiser, J. W., and van der Werf, G. R.: Historic global biomass burning emissions for CMIP6 (BB4CMIP) based on merging satellite observations with proxies and fire models (1750-2015), Geosci. Model Dev., 10, 3329-3357, https://doi.org/10.5194/gmd-10-3329-2017, $2017 \mathrm{~b}$.

Vuille, M., Bradley, R. S., and Keimig, F.: Interannual climate variability in the Central Andes and its relation to tropical Pacific and Atlantic forcing, J. Geophys. Res., 105, 12447-12460, 2000.

Vuille, M., Bradley, R. S., Healy, R., Werner, M., Hardy, D. R., Thompson, L. G., and Keimig, F.: Modeling $\delta^{18} \mathrm{O}$ in precipitation over the tropical Americas: Part II. Simulation of the stable isotope signal in Andean ice cores, J. Geophys. Res., 108, 4175, https://doi.org/10.1029/2001JD002039, 2003.

Wang, M., Xu, B., Kaspari, S. D., Gleixner, G., Schwab, V. F., Zhao, H., Wang, H., and Yao, P.: Century-long record of black carbon in an ice core from the Eastern Pamirs: Estimated contributions from biomass burning, Atmos. Environ., 115, 79-88, 2015.

Wang, Z., Chapellaz, J., Park, K., and Mak J. E.: Large variations in Southern Hemisphere biomass burning during the last 650 years, Science, 330, 1663-1666, 2010.

Wendl, I. A., Menking, J. A., Färber, R., Gysel, M., Kaspari, S. D., Laborde, M. J. G., and Schwikowski, M.: Optimized method for black carbon analysis in ice and snow using the Single Particle Soot Photometer, Atmos. Meas. Tech., 7, 2667-2681, https://doi.org/10.5194/amt-7-2667-2014, 2014.
Wiedensholer, A., Andrade, M., Weinhold, K., Mueller, T., Birmili, W., Velarde, F., Moreno, I., Forno, R., Sanchez, M. F., Laj, P., Whiteman, D. N., Krejci, R., Sellegri, K., and Reichler, T.: Black carbon emission and transport mechanisms to the free troposphere at the La Paz/El Alto (Bolivia) metropolitan area based on the Day of Census (2012), Atmos. Environ., 194, 158-169, 2018.

Wolter, K. and Timlin, M. S.: Monitoring ENSO in COADS with a seasonally adjusted principal component index. Proceedings of the 17th Climate Diagnostics Workshop, Norman, OK, NOAA/NMC/CAC, NSSL, Oklahoma Climate Survey, CIMMS and the School of Meteorology, University of Oklahoma, Norman, OK, 52-57, 1993.

Wolter, K. and Timlin, M. S.: Measuring the strength of ENSO events - how does 1997/98 rank?, Weather, 53, 315-324, 1998.

Wolter, K. and Timlin, M. S.: El Niño/Southern Oscillation behaviour since 1871 as diagnosed in an extended multivariate ENSO index (MEI.ext), Int. J. Climatol., 31, 1074-1087, 2011.

Zech, R., Kull, Ch., Kubik, P. W., and Veit, H.: LGM and Late Glacial glacier advances in the Cordillera Real and Cochabamba (Bolivia) deduced from ${ }^{10} \mathrm{Be}$ surface exposure dating, Clim. Past, 3, 623-635, https://doi.org/10.5194/cp-3-623-2007, 2007.

Zennaro, P., Kehrwald, N., McConnell, J. R., Schüpbach, S., Maselli, O. J., Marlon, J., Vallelonga, P., Leuenberger, D., Zangrando, R., Spolaor, A., Borrotti, M., Barbaro, E., Gambaro, A., and Barbante, C.: Fire in ice: two millennia of boreal forest fire history from the Greenland NEEM ice core, Clim. Past, 10, 19051924, https://doi.org/10.5194/cp-10-1905-2014, 2014 